8. Repov Š. The multi-component model of working memory: Explorations in experimental cognitive psychology / Š. Repov, A. Baddeley // Neuroscience. - 2006. - V. 139, Is. 1. - P. 5-21.

9. Sauseng P. What does phase information of oscillatory brain activity tell us about cognitive processes? / P. Sauseng, W. Klimesch // Neuroscience \& Biobehavioral Reviews. - 2008. - V. 32 (5). - P. 1001-1013.

10. Schroeder C. Low-frequency neuronal oscillations as instruments of sensory selection / C. Schroeder, P. Lakatos // Trends in Neurosciences. - 2009. - V. 32 (1). - P. 9-18.

11. Theta synchronization during episodic retrieval: neural correlates of conscious awareness / W. Klimesch, M. Doppelmayr, A. Yonelinas, N. Kroll, M. Lazzara, D. RoËhm, W. Gruber // Cogn. Brain Res. - 2001b. V.12. - P. 33-38.

12. Werkle-Bergner M. Cortical EEG correlates of successful memory encoding: Implications for lifespan comparisons. Review / M. Werkle-Bergner, V. Müller, Shu-Chen Li, U. Lindenberger // Neuroscience and Biobehavioral Reviews. - 2006. - V. 30. - P. 839-854

Мавромати Татьяна, Филимонова Наталья, Зима Игорь. Половые отличия в активности головного мозга человека при тестировании ассоциативной памяти. В работе исследуется активность головного мозга при запоминании ассоциаций разных типов у мужчин и женщин. Обследуемые (40 людей - 20 женщин и

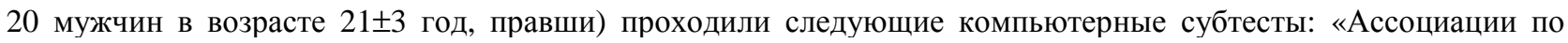
сходству», «Ассоциации по смежности по времени» и «Ассоциации по смежности по пространству». У всех обследуемых регистрировали ЭЭГ до начала обследования и во время проведения тестирования. Установлено, что запоминание ассоциации по сходству у женщин происходило с привлечением слуховой памяти, семантического анализа, интермодальних взаимодействий и создания зрительных образов ассоциативных пар слов, в то время как мужчины запоминали пары слов с помощью их проговаривания. Запоминание ассоциаций по смежности по времени для женщин оказалось наиболее сложным и потребовало привлечения задней ассоциативной коры обоих полушарий. Запоминание ассоциаций по смежности по пространству у мужчин происходило фактически с помощью механизмов их представления и проговаривания, в отличии от женщин, которые, в свою очередь, запоминали указанную информацию с помощью как её образного представления, так и вербального семантического анализа.

Ключевые слова: ассоциативная память, ЭЭГ, активность головного мозга, вербальные ассоциации по сходству, вербальные ассоциации по смежности.

Mavromati Tetiana, Filimonova Nataliya, Zima Igor. Sex differences in the Human Brain Activity During the Associative Memory Testing. In this paper the activity of the brain during memorization of the different types of associations in men and women. The subjects (20 women and 20 men aged $21+/-3$ Year, right-handers) held the following computer subtests «Association by similarity», «Association by contiguity in time» and «Association by contiguity in space». All subjects recorded EEG before the test and during the tests. It was found that the memorization of the similarity associations in women took place with the involvement of the auditory memory, semantic analysis, intermodal interaction and visual images associative word pairs, while the men memorized pairs of words with the help of pronunciation. Memorization of the associations by contiguity in time in women has been the most difficult and required the use of the back of the association cortex of both hemispheres. Memorization of the associations by contiguity in space (spatial) in men happened, factuality, through mechanisms of representation and of pronunciation, as opposed to women, who in turn memorized this information by both its figurative representation, verbal and semantic analysis.

Key words: Associative memory, EEG, activity of the brain, verbal associations by similarity, verbal associations by contiguity.

Стаття надійшла до редколегії 20.09.2015 p.

УДК 611.81:612.13-055.1

Володимир Пшибельський

\title{
Особливості стану показників мозкового кровообігу в чоловіків, які зайняті в промисловості
}

Проаналізовано та вивчено особливості мозкового кровообігу в осіб чоловічої статі, які зайняті в промисловому виробництві, і тих, котрі проживають у відносно чистих екологічних зонах. Виявлено статистично відмінні значення церебрального кровообігу між двома групами досліджуваних. У групі осіб, зайнятих у

(ㄷ) Пиибельський В., 2015 
промисловому виробництві, відзначено статистично нижчі значення показників періоду пульсового кровонаповнення, періоду повільного кровонаповнення й діастолічного індексу. Також у цій групі респондентів відзначено помірну асиметрію кровонаповнення та значне затруднення венозного відтоку 3 обох сторін досліджуваної ділянки. Простежено незначне зниження тонусу судин розподілу, що не є патологічним. У групі осіб екологічно чистих зон значення показників мозкового кровотоку перебуває в межах норми.

Ключові слова: промисловість, мозковий кровообіг, екологічно чиста зона, реоенцефалографія.

Постановка наукової проблеми та ії значення. Судинні захворювання головного мозку залишаються однією $з$ пріоритетних проблем світової медицини у зв’язку 3 їх поширенням, високою смертністю, інвалідністю й значними затратами на лікування та профілактику. Це одна 3 найважливіших проблем у нашій державі й у більшості економічно розвинутих країн світу, завдяки значному розповсюдженню та тяжким наслідкам судинних захворювань головного мозку [4].

Вивчення особливостей мозкової гемодинаміки в робітників, які зайняті в промисловому виробництві, обумовлене тим, що при роботі в цехах великих підприємств до численних професійних шкідливих чинників приєднуються мікроклімат, тривале статичне навантаження, сукупність різних токсичних речовин на одному робочому місці, а також підвищена чи низька температура при високій відносній вологості [3]. Тривала напруга компенсаторних механізмів у сполученні з інтенсивним фізичним навантаженням швидко призводить до порушення адаптації, розвитку патологічних змін у центральній нервовій системі, серцевосудинної, дихальної й інших системах організму. Ураховуючи той факт, що особи, які піддаються негативному впливу промисловості, потребують діагностики та дослідження за допомогою методу реонцефалографії $[1,7]$.

Реоенцефалографія - це неінвазивний метод дослідження судинної системи головного мозку. Цей метод дає змогу отримати об'єктивну інформацію про тонус, еластичність стінки й реактивність судин мозку, периферичний судинний опір, величину пульсового кровонаповнення. Аналізуючи реограму, ураховують іiі форму, використовують цифрові параметри, які дають змогу об' єктивно оцінювати стан судин. При цьому важливі особливості реоенцефалограми, які залежать від віку досліджуваних. Під час досліджень використовують спеціальні функціональні проби, які дають можливість розрізнити функціональні й органічні зміни. Найбілыш часто використовують пробу з нітрогліцерином, повороти голови, зміни положення тіла [5]. А перевагами цього методу є його відносна простота, можливість проведення дослідження практично в будь-яких умовах і під час тривалого часу, отримання роздільної інформації про стан артеріальної й венозної систем мозку та внутрішньомозкових судин різноманітного діаметра. Усе вищесказане й обумовлює актуальність нашого наукового дослідження.

Аналіз досліджень цісї проблеми. Аналізуючи літературні джерела, слід відзначити роботу Т. Ю. Гріненко стосовно оцінки функціонального стану головного мозку, у якій уперше досліджено особливості окислювальної модифікації білків, нейрогуморальних факторів, біоелектричної активності та гемодинаміки головного мозку стану якості життя хворих, які проживають у забруднених промислових районах [2].

Також учені розглядали стан вегетативної, серцево-судинної систем, мінеральний обмін у робітників, які працюють під впливом несприятливих виробничих чинників [6]. Однак залишається недостатньо вивченим питання мозкової гемодинаміки, що є досить актуальним для вирішення та застосування комплексних підходів для покращення роботи судинної системи осіб, котрі працюють на виробнитві.

Мета й завдання статті. Мета дослідження - вивчити особливості стану показників мозкового кровообігу в осіб чоловічої статті, які зайняті в промисловому виробництві. Відповідно до мети поставлено такі завдання:

- записати реоенцефалограму в осіб чоловічої статі, зайнятих у промисловому виробництві, та тих, які проживають в екологічно чистих зонах;

- проаналізувати основні показники церебрального кровотоку в досліджуваних групах;

- зробити порівняльний аналіз показників реоенцефалограми в обстежуваних промислового та екологічно чисто району.

Виклад основного матеріалу й обгрунтування отриманих результатів дослідження. Останнім часом у зв'язку з розширенням діагностичних можливостей і збільшенням точності одержуваних даних знову зріс інтерес до традиційного імпедансного методу діагностики судинної патології мозку - реоенцефалографії (РЕГ). Однак відсутність уніфікованого підходу до інтерпретації одержуваних даних вимагає створення єдиної системи опису реоенцефалограми й формулювання висновків. Тому ми використали принципи аналізу, розроблені М. А. Ронкін, Х. Х. Ярулліна, Ю. Т. Пушкарем і Л. Б. Івановим [5, 10]. 
Отримані результати засвідчили відмінність в особливостях мозкового кровотоку в досліджуваних осіб. Простежено статистичну відмінність значень основних показників реоенцефалограми між обстежуваними, зайнятими в промисловому виробництві, й осіб з екологічно чистих зон.

Період пульсового кровонаповнення - це показник, що характеризує об'ємне пульсове кровонаповнення, що є інтегральним показником і відбиває сумарне кровонаповнення досліджуваної ділянки біологічного об’єкта в систолу, визначається за величиною амплітудного показника реограми [6, 9]. Залежно від величини об'ємного пульсового кровонаповнення, цей показник може бути в межах норми, зниженим або підвищеним. Зниження об'ємного пульсового кровонаповнення поділяється на кілька ступенів: помірний - якщо значення менше за норму не більше $40 \%$; значний - якщо менше від норми на 40-60\%; різко виражений - якщо менше за норму на 60-90\%; і критичний - коли амплітуда реоенцефалограми межує з технічними можливостями реографа [10].

Як видно з рис. 1, значення періоду пульсового кровонаповнення статистично вищі в групі осіб промислової зайнятості, порівняно з особами з екологічно чистих зон. Це вказує на те, що об'ємний кровотік у першій групі досліджуваних є дещо зниженим, але не патологічним. Проте слід зауважити, що зниження значення показника більше ніж на 60-90 \% призводить до патологічного стану й украй негативних наслідків.

Наступний етап - оцінка коефіцієнта асиметрії (КА). Це досить важливий показник, за яким можна визначити різницю кровонаповнення як усередині досліджуваного басейну, так і між півкулями. Залежно від величини коефіцієнта асиметрії розрізняють кілька ступенів асиметрії кровонаповнення, якщо коефіцієнт дорівнює 7 \% і менше, то суттєвої асиметрії кровонаповнення немає, при значенні коефіцієнта асиметрії 8-14 \%, асиметрію кровонаповнення характеризують як невелику. Якщо коефіцієнт асиметрії становить 15-25\%, то це свідчить про наявність помірної асиметрії кровонаповнення, при коефіцієнтові $26 \%$ і більше він розцінюється як значний $[4,7]$.

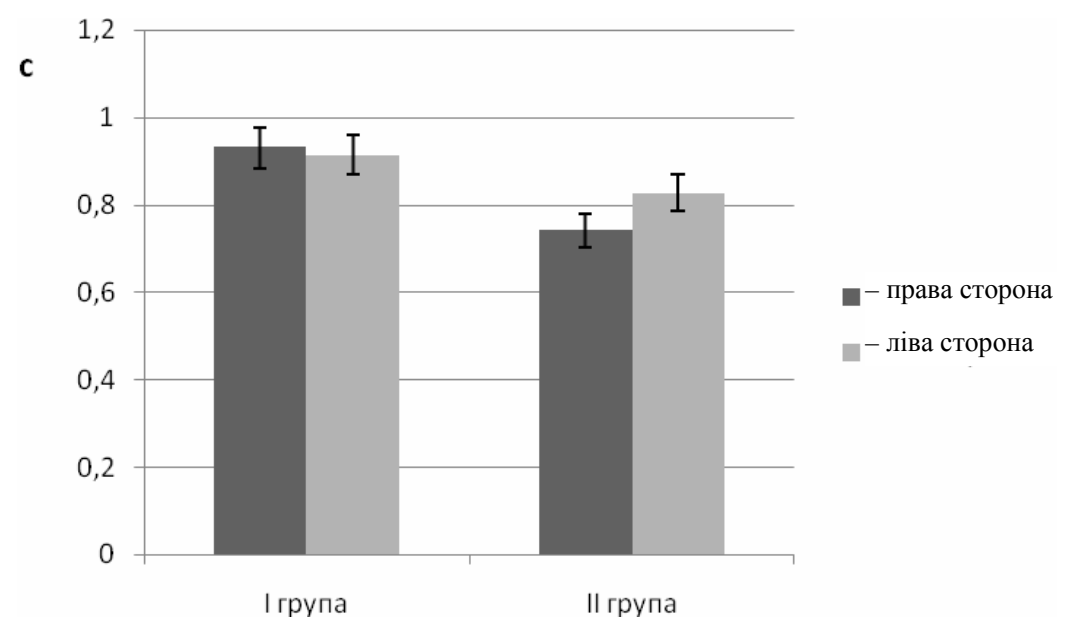

Рис. 1. Період пульсового кровонаповнення (с) у досліджуваних осіб

На основі наших досліджень відзначено незначну асиметрію кровонаповнення всередині досліджуваного басейну. Його значення коливалося в межах 8-14 \%. Перша группа відзначилася значенням $12 \%$, а друга $-15 \%$.

Не менш важливою та інформативною є оцінка тонусу магістральних артерій (артерій розподілу), яка здійснюється за швидкісними показниками. Таким показником, зокрема, є максимальна швидкість періоду швидкого наповнення, що визначається за допомогою диференціальної реограми. Залежно від величини періоду швидкого наповнення розрізняють такі стани тонусу артерій розподілу: у межах норми; підвищений якщо значення нижче за норму; знижений - якщо значення вище за норму $[3,5]$.

Якщо період пульсового кровонаповнення перебуває на нижній межі норми, то відзначають наявність тенденції до підвищення тонусу артерій розподілу, а якщо на верхній межі норми, то це тенденція до зниження тонусу. При зниженні показника більше ніж на 50 \% від норми констатується гіпертонус, а при підвищенні понад $50 \%$ - гіпотонус $[2,10]$.

Аналіз наших досліджень засвідчив статистично значиму відмінність даних цього показника. Група осіб, зайнятих у промисловому виробництві, характеризувалася статистичним зниженням періоду пульсового коливання, порівняно 3 представниками 3 екологічно чистих зон (рис. 2.). Це свідчить про підвищення тонусу артерій розподілу, тобто простежено явище гіпертонусу. 


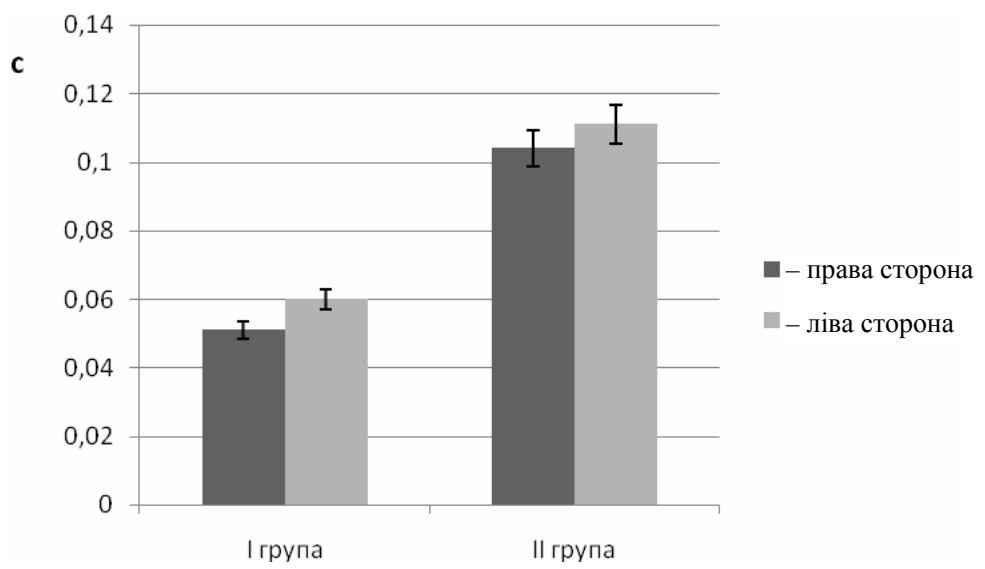

Рис. 2. Період повільного кровонаповнення (с) у досліджуваних осіб

Аналіз церебрального кровотоку оцінювали також за показниками, що характеризують тонус артерій середнього й дрібного калібру (артерій опору). Оцінюється цей показник, як і тонус артерій розподілу за швидкісними показниками, а саме за швидкістю періоду повільного кровонаповнення. Залежно від величини цього показника його оцінку визначають за алгоритмом стану тонусу артерій розподілу [8]. Отримані дані свідчать про тенденцію до зниження значень періоду повільного кровонаповнення в першій групі осіб - 0,090 $\pm 0,13$ та 0,121 $\pm 0,02-$ у другій. Ці значення зафіксовано в правій стороні кровонаповнення басейну й у лівій відзначено такі значення: 0,089 $\pm 0,12-$ у першій групі обстежуваних та 0,124 \pm $0,02-$ у другій.

Реоенцефалограма також дає змогу побічно судити про стан венозного відтоку. При цьому використовують діастолічний індекс, оскільки доведено генез діастолічної хвилі (сумація хвиль відображення).

Якщо цей показник перебуває в межах норми, то зазначається, що венозний відтік не ускладнений, а якщо ж менше норми - венозний відтік утруднений за дефіцитним типом. При значенні цього показника, що вищий за норму, простежено утруднення венозного відтоку (невелике при значеннях у межах 0,70-0,80, значне - якщо понад 0,80 ) [5].

Значення показника в нашому дослідженні характеризувалося статистично вищими значеннями цього показника в першій групі. Це призводить до утрудненого венозного відтоку, причому з обох сторін (рис. 3).

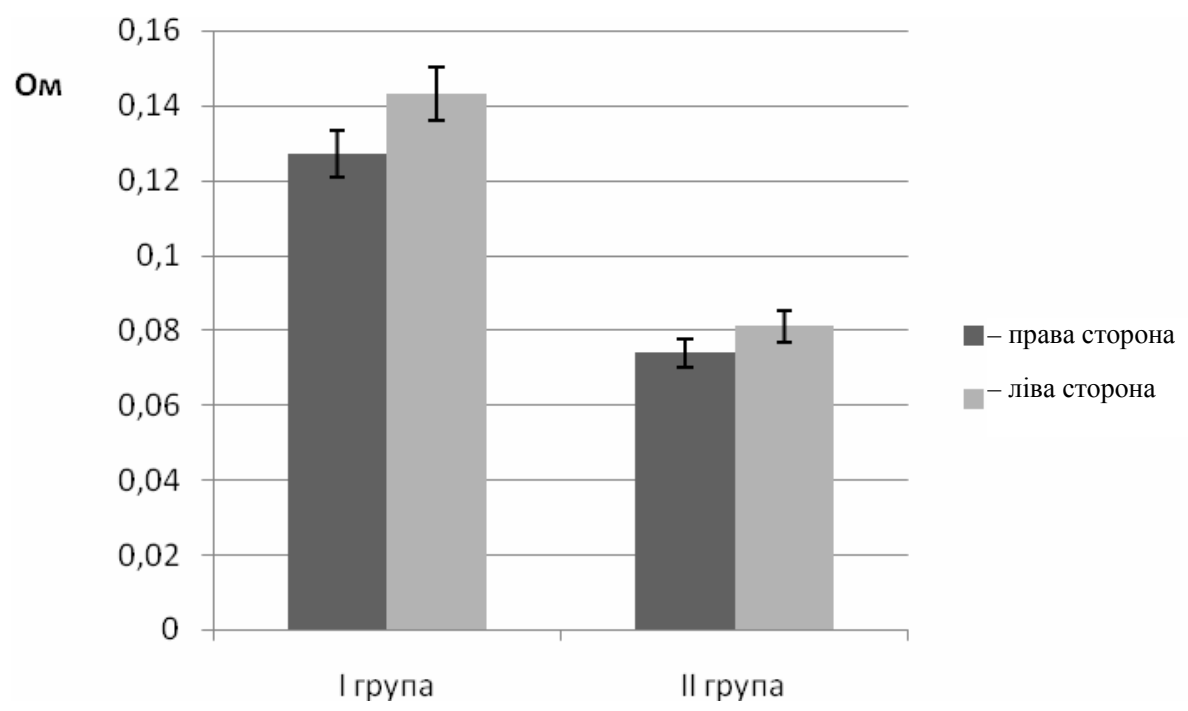

Рис. 3. Діастолічний індекс (Ом) у досліджуваних осіб 
Отримавши дані, ми зробили висновок, що перша група осіб, зайнятих у промисловому виробництві, характеризується зниженим об'ємним кровотоком, ударним об'ємом крові й тонусом судин дрібного калібру, а тонус стінок судин середнього калібру - підвищений. Відзначені статистично значимі затруднення венозного відтоку з обох сторін досліджуваної ділянки. Також слід указати на зниження периферичного опору, що ускладнює висхідний процес кровообігу до досліджуваної ділянки.

Оскільки організм людини піддається дії різних негативних промислових чинників, то внаслідок цього порушуються функціональні можливості організму та, як наслідок, - зниження працездатності й виникнення різних професійних хвороб з украй негативними наслідками.

Висновки та перспективи подальших досліджень. У групі осіб, які зайняті в промисловому виробництві, відзначені статистично нижчі значення періоду пульсового кровонаповнення, періоду повільного кровонаповнення й діастолічного індексу. Це вказує на те, що об'ємний церебральний кровотік значно знижений, тонус артерій розподілу підвищений, а тонус артерій опору знижений. У групі осіб, зайнятих у промисловості, простежено помірну асиметрію кровонаповнення та значне затруднення венозного відтоку з обох сторін досліджуваної ділянки. Це вказує на недостатність кровообігу за магістральним типом і відносно нестійкий судинний тонус на рівні артерій опору, а реактивність судин $є$ незадовільною. У групі осіб з екологічно чистих зон показники перебувають у межах норми. Простежено незначне зниження тонусу судин розподілу, що не є вагомим. Це засвідчує стійкий судинний тонус, адекватну реактивність і задовільний стан мозкового кровонаповнення.

\section{Джерела та література}

1. Архіпова Г. І. Вплив летких органічних сполук лакофарб них матеріалів на організм працівників промислових підприємств / Г. І. Архіпова, А. О. Падун, К. Т. Погосова // Вісник НАУ, - 2010. - № 1. C. $127-132$.

2. Бахтояров П. Д. Початкові порушення кровопостачання головного мозку у робітників великого промислового пудприєсмтва Донбасу, їх корекція методами магнітотерапії і рефлексотерапії : автореф. дис. ... канд. мед. наук / П. Д. Бахтояров. - К., 2003. - 25 с.

3. Кузнецов А. А. О естественной нормализации диаграммы ритма сердца / А. А. Кузнецов, С. А. Пермяков // Труды Нижегородского государственного технического университета им. Р. Е. Алексеева. Нижний Новгород, 2012. - Т. 78, №4 (97). - С. 363-368.

4. Лобойко О. I. Клініко-патофізіологічна характеристика співвідношень церебральних та серцевосудинних порушень у віддалений період закритих черепно-мозкових травм : автореф. дис. ... канд. мед. наук / О. І. Лобойко. - Х., 2000. - 25 с.

5. Ронкин М. А. Реография в клинической практике / М. А. Ронкин, Л. Б. Иванов. - М., 1997. - 40 с.

6. Севальнєв А. І. Професійна захворюваність на підприємствах чорної металургії / А. І. Севальнєв, Л. П. Шаравара // Медицина сьогодні і завтра. - 2013. - № 3 (60). - С. 160-163.

7. Слободинський А. П. Вплив промислових аерозолів на динаміку пневмоконіозу в Україні / А. П. Слободинський, І. В. Васильківський, В. Г. Петрук, С. М. Кватернюк // Міжнародна науково-практична конференція «Наука. Молодь. Екологія» в рамках I Всеукроїнського молодіжного з'їзду екологів 3 міжнародною участю». - 2014. - С. 194-198.

8. Тайцлин В. И. Кожно-сосудистая реакция на никотиновую кислоту больных с последствиями черепномозговых травм / В. И. Тайцлин, О. И. Лобойко // Український вісник психоневрології. - Т. 7. - Вип. №1 (19). - Х., 1999. - С. 103-104.

9. Широбоков А. В. Исследование интегральных показателей сердечно-сосудистой деятельности в зависимости от антропогенных и климатических факторов / А. В. Широбоков, Е. Г. Яскин, Т. А. Трифонова и др. // Известия Самарского научного центра Российской академии наук. - 2013. - Т. 15, № 3 (6). - С. 20082011.

10. Яруллин Х. Х. Клиническая реоэнцефалография / Х. Х. Яруллин. - М. : Медицина, 1983. - 271 с.

Пшибельський Владимир. Влияние промышленности на мозговое кровообращение у лиц мужского пола. Проанализированы и изучены особенности мозгового кровообращения у лиц мужского пола, занятых в промышленном производстве, и тех, которые проживают в относительно экологически чистых зонах. Установлены статистически отличные значения мозгового кровообращения между двумя группами испытуемых. В группе лиц, занятых в промышленном производстве, отмечены значения, статистически ниже периода пульсового кровенаполнения, периода медленного кровенаполнения и диастолического индекса. Также у этих лиц отмечается умеренная асимметрия кровенаполнения и значительное затруднение венозного оттока с обеих сторон исследуемого участка. В группе лиц экологически чистых зон значения показателей находится в 
пределах нормы. Наблюдается незначительное снижение тонуса сосудов распределения, что не является патологическим.

Ключевые слова: промышленность, мозговое кровообращение, экологически чистая зона, реоэнцефалография.

Pshybelskyi Vladimir. The Impact of Industry on Cerebral Blood Flow in Males. Analyzed and studied the features of cerebral blood flow in males who are engaged in industrial production and persons living in a relatively ecologically clean areas. A statistically different values of cerebral blood flow between the two groups studied. In the group of persons employed in industrial production observed statistically lower values of pulse blood filling period, a period of slow and diastolic blood filling index. Also in these individuals observed moderate asymmetry blood supply and venous drainage trouble impressive on both sides of the investigated area. In the group of persons ecologically clean areas mentioned indicators are within normal limits. There is a slight decrease in vascular tone distribution, which is not abnormal.

Key words: industry, cerebral blood flow, ecologically clean area, rheoencephalography.

Стаття надійшла до редколегії 20.09.2015 p.

УдК 612.6:371.72

\author{
Юрій Трофим'як, \\ Олена Дмитроца, \\ Світлана Швайко
}

\title{
Порівняльна характеристика фізичного розвитку молодших школярів залежно від місця проживання
}

Вивчено особливості фізичного розвитку школярів молодшого шкільного віку, які проживають у міській та сільській місцевостях. У результаті дослідження встановлено, що показники фізичного розвитку молодших школярів відповідали середньому рівню; серед обстежуваних із сільської місцевості найчастіше трапляються випадки з нормативними або підвищеними показниками рівня фізичного розвитку.

Ключові слова: фізичний розвиток, молодший шкільний вік, антропометричний показник, місце проживання.

Постановка наукової проблеми та її значення. Унікальний критерій здоров’я населення - фізичний розвиток, за ознаками якого можна простежити і глобальні зміни біології природи людини, і порівняно короткотривалі зміни в популяції $[1 ; 5 ; 8]$. Фізичний розвиток $\epsilon$ сукупністю морфологічних та функціональних властивостей організму, що характеризують процес його росту й розвитку. Указані характеристики залежать як від спадковості, так і від складного комплексу соціально-гігієнічних умов. Оскільки процеси росту та розвитку організму дитини шкільного віку $є$ незавершеними, то він чутливий до впливу змін у навколишньому середовищі (екологічних, соціально-побутових, економічних, географічних тощо) [3; 12].

Фізичний розвиток - один із провідних критеріїв оцінки стану здоров'я учнів, важливий і доступний для вимірювання, оцінки та інтеграції. Згідно з даними наукових джерел, постійних і єдиних стандартів антропометричних показників для всіх дітей бути не може, оскільки вони змінюються залежно від соціально-побутових та клімато-географічних умов життя. Важливим $\epsilon$ вивчення регіональних показників фізичного розвитку з їх регулярним оновленням кожні 5-7 років [3;5; 8; 15].

Комплексна оцінка фізичного розвитку дитини полягає у визначенні рівня фізичного розвитку (за довжиною тіла), гармонійності фізичного розвитку (за масою тіла, окружністю грудної клітини та показниками функціонального стану) $[6,12]$. Рівень фізичного розвитку відіграє особливу роль під час установленя стану здоров'я учнів, організм яких перебуває в стадії формування й через свою пластичність надзвичайно схильний як до позитивних, так і до негативних впливів факторів зовнішнього середовища. Тому показники фізичного розвитку відображають не лише стан здоров'я дітей i підлітків, а й соціально-економічні та соціально-гігієнічні умови їхнього життя, рівень і якість організації.

( Трофим’як Ю., Дмитроияа О., Швайко С., 2015 